\title{
EchoGéo
}

52 | 2020

Ho Chi Minh Ville, terrain de jeu(x) métropolitain(s)

\section{Visualizing the invisible: COVID-19 pandemic season in Saigon \\ Billet}

\section{Christophe Robert}

\section{OpenEdition}

Journals

\section{Electronic version}

URL: https://journals.openedition.org/echogeo/19692

DOI: 10.4000/echogeo.19692

ISSN: 1963-1197

\section{Publisher}

Pôle de recherche pour l'organisation et la diffusion de l'information géographique (CNRS UMR 8586)

\section{Electronic reference}

Christophe Robert, "Visualizing the invisible: COVID-19 pandemic season in Saigon", EchoGéo [Online], 52 | 2020, Online since 30 July 2020, connection on 10 August 2021. URL: http://

journals.openedition.org/echogeo/19692 ; DOI: https://doi.org/10.4000/echogeo.19692

This text was automatically generated on 10 August 2021.

EchoGéo est mis à disposition selon les termes de la licence Creative Commons Attribution - Pas

d'Utilisation Commerciale - Pas de Modification 4.0 International (CC BY-NC-ND) 


\title{
Visualizing the invisible: COVID-19 pandemic season in Saigon
}

Billet

\author{
Christophe Robert
}

1 It is difficult to photograph something invisible. Yet the invisibility of this new Coronavirus has had intensely visible effects on the fabric of cities globally, and on nature and wild fauna as well. These visual vignettes provide images of the COVID-19 pandemic season in Saigon from February to May 2020. Saigon was officially renamed Ho Chi Minh City in 1976, but few locals use the official name of the city in daily interactions.

2 From late January 2020 life in Saigon and in Vietnam has gone on. It has been disrupted by COVID-19 in complex ways. These images register some of the disruptions and intend to disrupt, too, by calling attention to textures and sensations, and senses of place and self in daily life in the everyday, banal settings of the city as it is lived and experienced. If you look closely and if you know or reminisce about the histories and the stories of these places, suddenly new echoes rise. New images, recollections, and ideas emerge. Images collide and scramble usual daily rhythms and ways of seeing. These images give you a new experience of the city and document, in a snapshot, a vignette of these pandemic times that will fade quickly and leave more economic devastation in their wake.

In this series, I never try to be exhaustive or have the last interpretive word. Where would you look for completeness in this situation? Instead, these vignettes are similar to the stories I hear and overhear in the streets, and collected and discussed with Vietnamese, in Vietnamese, since my first ethnographic project in Vietnam in the mid-1990s.

$4 \quad$ My aim is to provide new or different viewpoints and ways of looking. Like stories told and heard on street corners, they are often taken for granted - invisible, forgotten, habitual or routine. Here, photographs help by providing images of thought. "Denkbilder" (thought-images) was the term Walter Benjamin coined to convey his understanding of history in which images release a flash of insight through disruptive 
reading and collisions of different times and spaces - as in his analyses of panoramas, the new architecture of the Paris passages, street barricades, and claustrophobic bourgeois interiors in "Paris, Capital of the Nineteenth Century" (Benjamin, 2006; Cadava, 1997).

5 Thought-images enable brief moments of illumination. New insights arise from reflecting on an eerie difference, newness, a new disrupted temporality. In this pandemic season the most basic spaces of daily life can no longer be taken for granted either, nor simply the ability to live, study, work or play as before.

Illustration 1 - Main visual trope of the pandemic in Vietnam: deserted streets (District 1, Ho Chi Minh City)

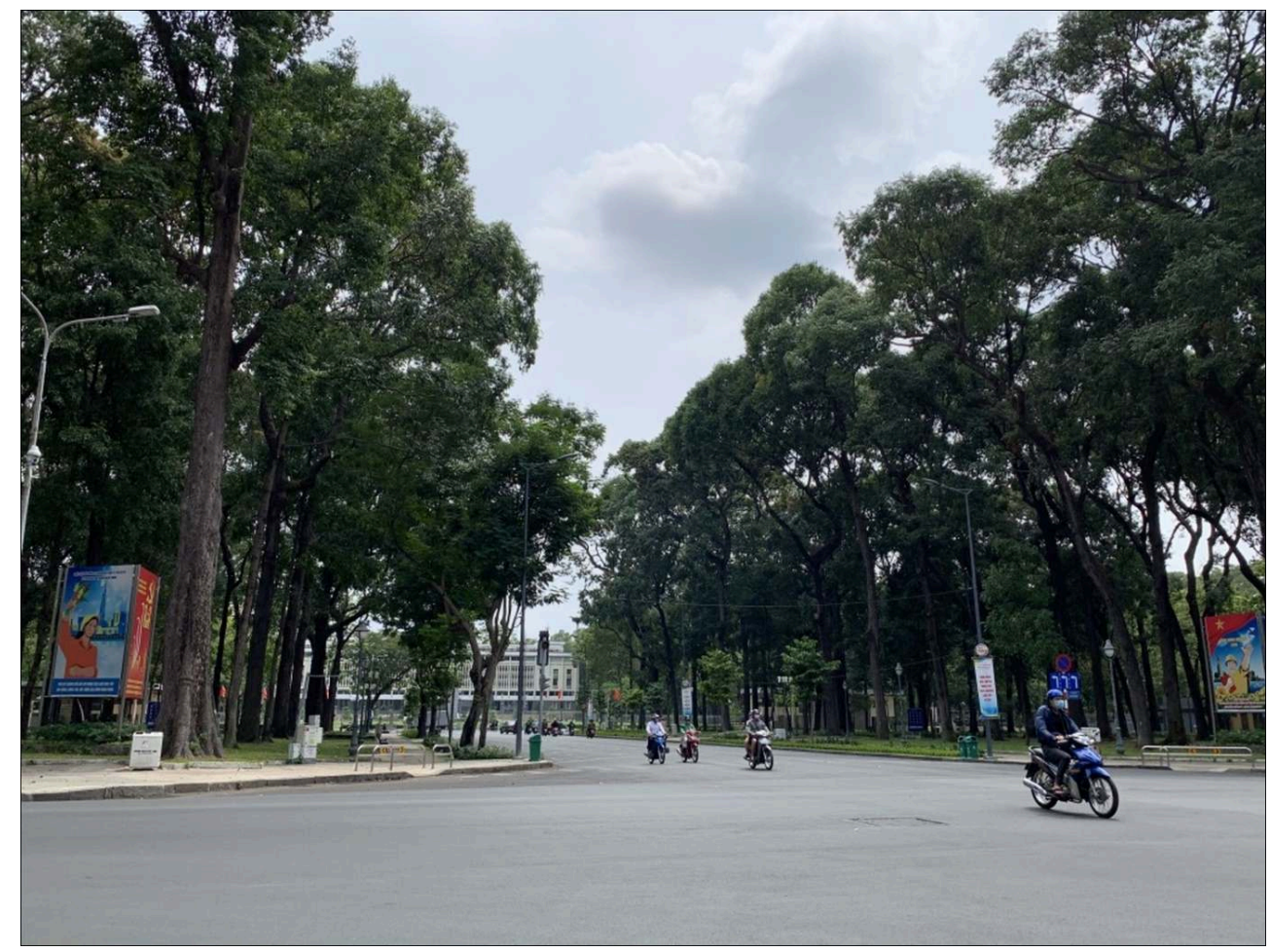

Author: C. Robert, April 11, 2020.

6 This image is one main visual trope of the pandemic in Vietnam and globally. Deserted streets, empty roadways, no traffic, few people: all suggest visually the massive impacts of this pandemic on economic activity and social life. This prints well, as journalists say. At the height of lockdown, global news organizations, later copied by Vietnamese media, ran "before and after" features on COVID, to imprint visually the fact of absence - in large boulevards, usually crowded central business districts and shopping centers, now photographed in their utter emptiness ${ }^{1}$. Terms such as post-apocalyptic emerged in Vietnam and globally to register the shock of the disappearance of people and traffic.

7 I see other things in this photograph. I see the new CCTV cameras that have been installed at all intersections of the city and in the smallest streets and alleys over the last five years. I see the same propaganda posters that have occupied the same location since I began to conduct anthropological research in Saigon in the 1990s. What I see is not the apocalypse. I see an image of traffic in this iconic intersection in front of Reunification Palace (renamed Independence Palace since 2016) that brings to mind 
traffic in 1999. I am at once transported back in time and propelled into the future. What will happen next? When will this pandemic stop? When will the loud, choking traffic resume again and the aggressive new car drivers return?

The sudden emptiness, the lack of tourists is of course due to COVID-19. Hotels and restaurants were closed and the Vietnamese government finally suspended flights into Vietnam at the end of March 2020. Foreign tourists in fact kept visiting Vietnam until the end of March. Cruise ships docked or were turned back in confusing episodes. What is missing in this picture are groups of foreign, mostly white, European, Australian, and American tourists walking down these streets, sweating and panting in the brutal heat, followed by street sellers proposing cold water and trinkets.

The face mask is a key global symbol of the COVID-19 pandemic. These billboards went up quickly in February and March across the city and the entire country.

Illustration 2 - Face masks, key global symbols of the COVID-19 pandemic (District 1, Ho Chi Minh City)

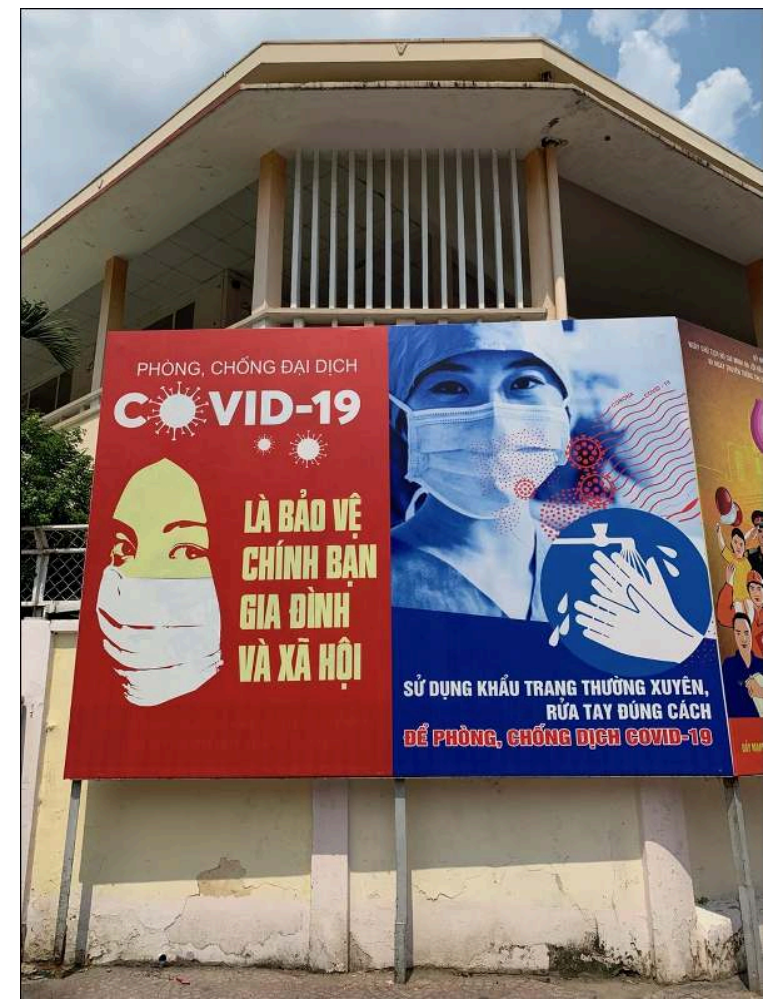

Author: C. Robert, April 30, 2020.

Older artists who participated in the American War and who were no longer active volunteered to help produce quickly a new set of images for the campaigns to fight against the pandemic. "In a war, we draw," is how one of these artists coming out of retirement put it to a journalist in April $2020^{2}$. Younger artists also joined the effort and contributed their work, as is visible on the left panel.

11 The red billboard is remarkable for its stark, confident, stylized design and use of colors. The title caption reminds passersby and traffic to struggle and fight against COVID-19, and reprises the term "struggle and fight" from the anti-colonial revolutionary struggle and wars of national liberation against French colonizers and later American imperialists. Red, which symbolizes both the revolution and more 
traditionally, warmth, success, and life itself, contrasts with the white mask which is the punctum of this image (Barthes, 1981). The billboard is rebus-like. The image speaks and the woman addresses you directly: my eyes, my mask, my image, the fact of wearing a mask as represented here "is to protect yourself, [your] family and society." There is no subject in this sentence. We find here the usual performative speech of propaganda, and the metonymies and synecdoches by which each person in a poster becomes a figure representing a segment of the population. When represented in groups, these figures embody The People.

The young woman is a familiar figure. She is a stark reminder of COVID, certainly. Yet she was a common figure and sight in Vietnam long before the epidemic: the figure of the "ninja," as Saigon slang has it, her entire face and body covered to protect against dust, exhaust fumes, and sun while riding her scooter in traffic ${ }^{3}$. She is quite different from the figure on the right: here a female nurse, herself in a face mask, scrubs, and protective head gear tells you with friendly yet firm professional authority to wear a mask continually and wash your hands properly in order to struggle and fight against COVID-19. The same key theme of struggle and fighting repeats, emphasized in the red tones that here symbolize both emphasis and danger, as in viruses. The pedagogic image of hand washing is recycled from numerous public health campaigns by the government and international NGOs to teach proper hand washing to children, especially, to reduce risk of disease transmission. These images are rekindled in the context of this pandemic.

The eyes that stare at you are the defining feature of these masked figures. They convey the message by looking at you and drawing you to them, in the absence of the identifying features of a full human face. One fundamental aspect of these billboards is that, when asked, Vietnamese say they do not see them and do not pay attention to them. Billboards have been placed at this location since the 1990s and probably longer, in front of a modernist school building, on one of the major intersections of the city. Billboards are changed regularly throughout the year to mark the anniversaries of major revolutionary events and to stress political campaigns against crime or drug use. The repetition of similar anniversaries using the same images and styles, and the same formulaic language and slogans, year after year, render these political billboards invisible. People tune them out.

Compared to the 1990s, there are many fewer propaganda billboards and posters, as profitable advertising has taken over public spaces. Here, in an almost undetectable shift in meaning and function, these are public service or public health announcements. And yet they use the same political language of mobilization, are posted by the same government offices (here the Ministry of Health), and remain equally invisible. One can query the supposed invisibility of this propaganda by noticing that in prime locations of the city some much larger billboards are used alternatively for government messages and for advertising. The invisibility and lack of attention that people assert remains an open question, especially when similar messages and images are relayed constantly in media that are all state-controlled in Vietnam - and reappear in social media in forums and discussions.

Here, the now familiar images of COVID focused on empty streets, face masks, and public health campaigns shift to more familiar settings and daily practices. Yet here too significant changes and new realities are visible. 
Illustration 3 - An empty market, by Vietnamese standards (Binh Thanh District, Ho Chi Minh City)

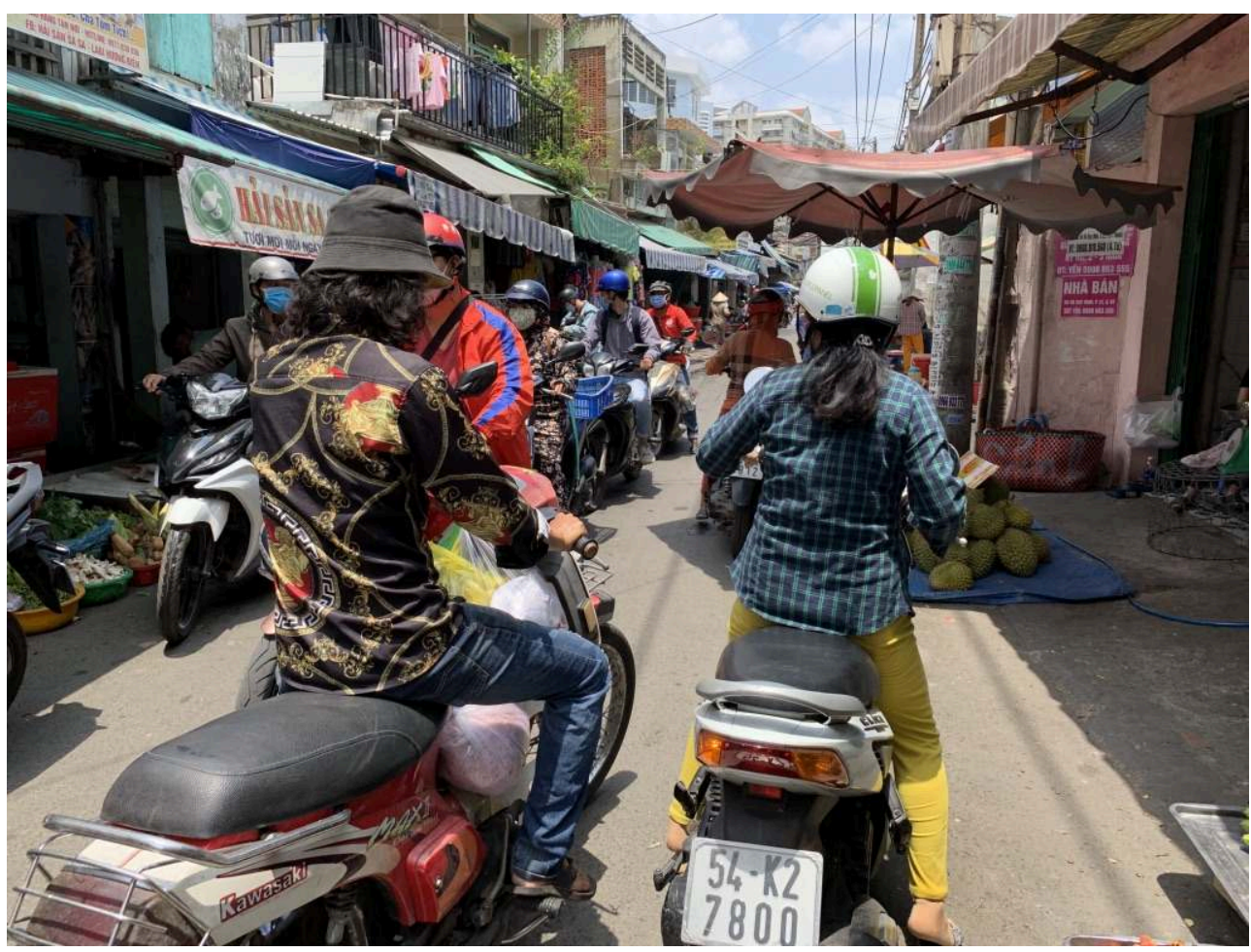

Author: Robert C., April 17, 2020.

16 This is actually an empty market, by Vietnamese standards, with few customers. Some of the non-essential shops are shuttered or empty. Compared to the usual crowding in this market, when motorbike riders weave and push their way through crowds of vehicles in the maze of lanes and alleys, this registers visually as a mid-morning scene of low activity. In street markets, as here, riders simply stop by a shop or by goods displayed directly on the ground. They make their way through the market and make purchases without dismounting and without turning the ignition off, before moving on. The pollution from exhaust fumes is intense and the "social distancing" required by this epidemic simply cannot be and is not maintained.

17 As I continue further down the street in this market, sidewalks and most of the stalls are empty. The eye focuses on masked figures, since this picture was taken during the three weeks in April when the government instituted stricter controls on movement, especially by banning inter-provincial travel and established checkpoints to enforce it. It was a time that most foreign observers and journalists and foreign residents in Vietnam called lockdown. Yet this was not lockdown at all. The guidelines from the government were actually to practice "social distancing" and to reduce non-essential activities that required leaving the house.

What was remarkable is that, in spite of successfully tackling the epidemic through testing, patient tracking and tracing, the authorities had no means to enforce an actual lockdown in which, as in Europe, people could not leave the house. This would have been utterly impossible to enforce in Vietnam. It would have precipitated an economic crisis much worse than the current enormous economic devastation, and would have completely disrupted food distribution in cities. One key reason is visible here. It simply has to do with ways in which the great majority of the population purchases 
food, the extremely complex social organization of the informal sector, and the millions of livelihoods that depend on arrangements displayed here.

Illustration 4 - An itinerant street seller (Binh Thanh District, Ho Chi Minh City)

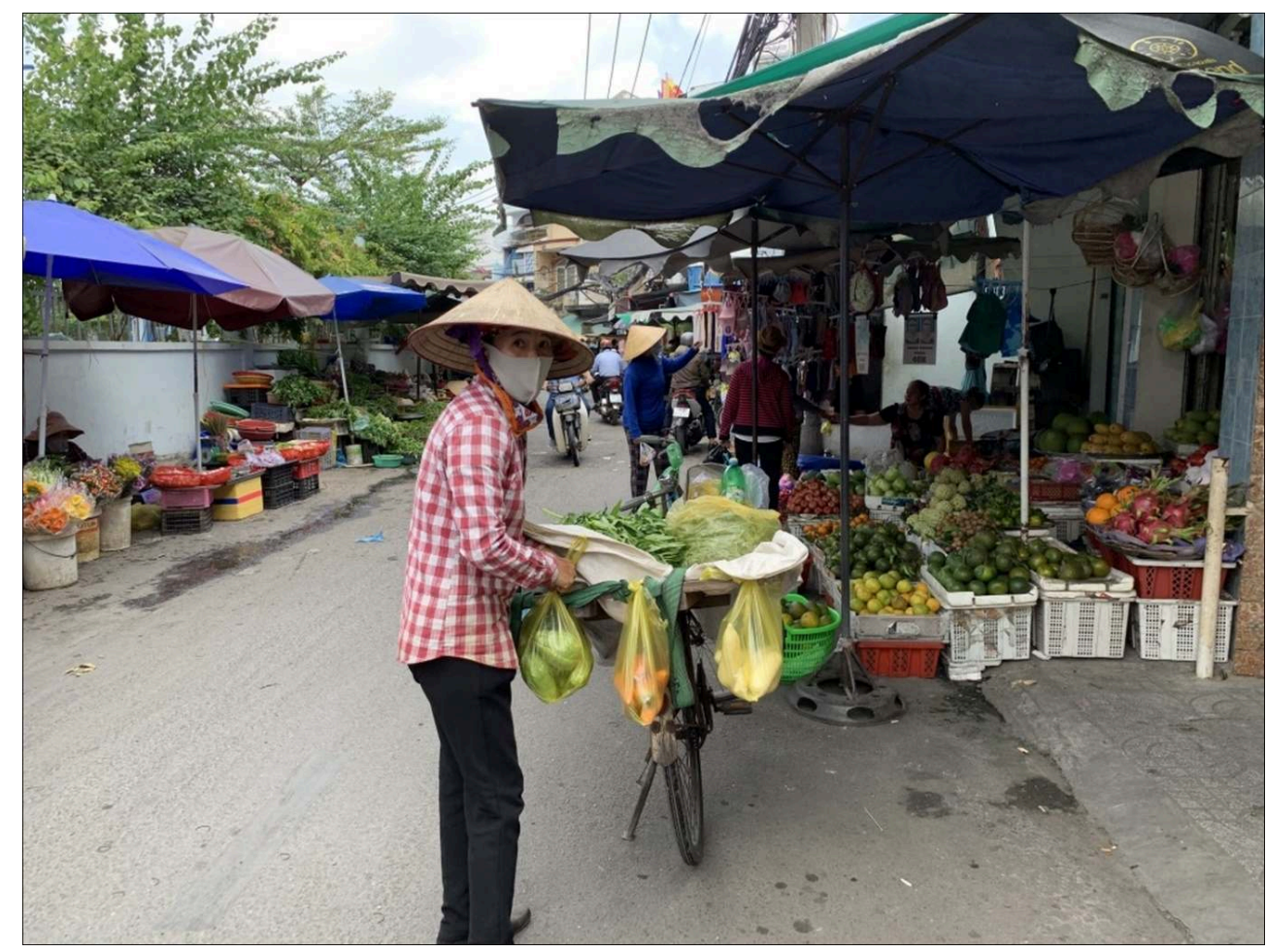

Author: C. Robert, April 17, 2020.

19 Among the women in conversation on the right, several are not wearing face masks. As I took the photograph the woman in the checkered shirt looked up. She is an itinerant food seller. Her old bicycle denotes her precarious economic status compared to the street market sellers from which she bought her stock. Her eyes are startled at seeing a Westerner here - though I too was wearing a face mask. I apologized and asked her respectfully in Vietnamese, by addressing her properly as older sister, if it was all right to take her photograph. Even more startled that I could speak the language clearly, and used the proper terms of address, she laughed and said it was fine. This is not an exotic anecdote. The lack of ability and desire to speak the language by most foreigners in Vietnam is a key source of hostility from Vietnamese who resent foreign expats - and this hostility is focused on white men. There are tensions with Japanese, Korean and Chinese businessmen (they are mostly men) who live and work in Vietnam. Yet a panAsian cultural argument is subsumed under a racial categorization that subdivides foreigners into "Asians like us" and "Westerners" and mirrors former colonial categories. The additional racial contradictions from the assumption that Western means white are usually left unresolved and unvoiced.

20 This came to a head brutally in March 2020 when articles appeared in Vietnamese media stating that "foreigners" (meaning Westerners, meaning whites) "disdained" Vietnamese and endangered the population by not wearing face masks ${ }^{4}$. This was picked up quickly by social media in Vietnam. 
Spending any amount of time in markets and street markets at the height of the epidemic revealed of course that many Vietnamese themselves didn't wear face masks. The issue was one of acquaintance. If one knew the person one dealt with, as here, it was fine not to wear a face mask, as if prior social relation protected against viral infection. As I witnessed and discussed, many would say that they took their face masks off or wore them on their chin, as below, when meeting a friend.

Illustration 5 - When face masks come off (Binh Thanh District, Ho Chi Minh City)

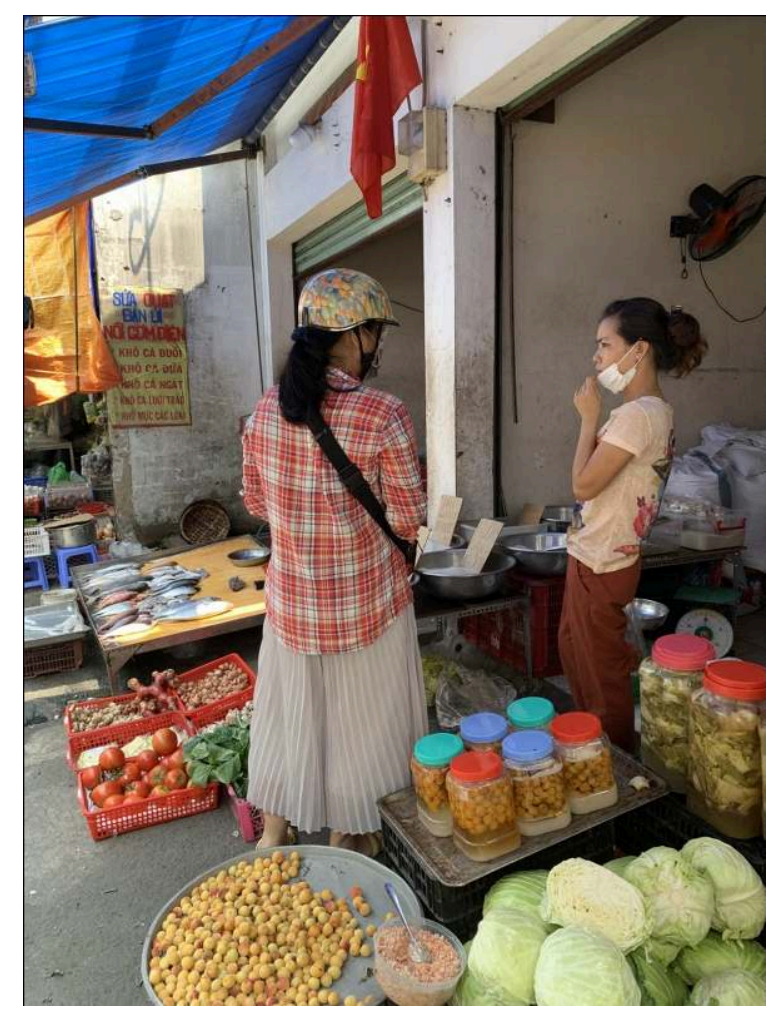

Author: C. Robert, April 19, 2020.

Women who shop in these markets, and even the stranger like me, develop relationships with market sellers in order to get the best and freshest produce or food at the fairest price after a quick negotiation. As one notices, no prices are indicated anywhere. One must know the price of every item one purchases in order to be able to buy at decent prices. Trust is important and ensures mutual benefits - steady clients, recommendations, and quality purchases. Many younger middle-class women say they "do not know how to buy at the market" because often their mothers, or maids in wealthier families, would do the market shopping in the morning when children were at school, and these social skills and networks of acquaintance were not passed on.

I wanted to end this brief stroll here, to point out a more complex social and public health picture than images of empty streets or stories of a fully mobilized population convey. In fact, as is often the case in post-war Vietnam, the language and visualization of mobilization are prominent and prominently displayed, without the corresponding, actual mobilization. In this pandemic season, life continued. This is not meant to sound ironic. One key issue is that the informal sector officially constitutes $50 \%$ of all employment in the city of Saigon, and in my view, quite a bit more. It is through these incredibly complex and flexible arrangements that are also based on the relentless 
exploitation of poorer segments of the population - as the itinerant street seller in the previous photograph - that Vietnam continued to function economically and to be fed and supplied. These markets and street stalls in particular played an essential role.

At the outset of the pandemic the central government in Hanoi imposed a narrative of war-like mobilization, equating citizenship with soldiering, in a crude set of repetitive and worn-out metaphors. The images and discourses of wartime mobilization against an invisible enemy flooded the airwaves and the public sphere during the height of COVID in Vietnam from February to late April, when people started congregating again and stopped wearing face masks. And yet, as in war, and certainly as during wartime in Vietnam, the women who sacrificed their safety to continue producing and selling food provide different sets of images and reference points, and a more complex and nuanced picture of daily life far removed from the martial tones of the men in power speaking in their names and in the name of the People.

\section{BIBLIOGRAPHY}

Barthes R., 1981. Camera Lucida: Reflections on Photography. New York, Hill and Wang, 199 p.

Benjamin W., 2006. The Writer of Modern Life. Cambridge, Harvard University Press, 307 p.

Cadava E., 1997. Words of Light: Theses on the Photography of History. Princeton, Princeton University Press, $173 \mathrm{p}$.

\section{NOTES}

1. https://www.saigoneer.com/saigon-news/18574-photos-an-empty-district-1-waits-for-itscrowds-to-return

2. https://www.theguardian.com/global-development/2020/apr/09/in-a-war-we-drawvietnams-artists-join-fight-against-COVID-19

3. https://e.vnexpress.net/projects/street-ninjas-battle-sexism-and-the-sun-invietnam-3651101/index.html

4. https://tuoitrenews.vn/news/features/20200322/foreigners-disdain-for-face-masks-worriesvietnamese/53584.html

\section{ABSTRACTS}

The COVID-19 pandemic disrupted daily life in Vietnam and Saigon/Ho Chi Minh City in ways that diverged from reporting in Vietnamese and foreign media. Images of empty streets with no 
traffic became features of Western reporting and were mimicked by Vietnamese media. Yet, in alleyways and smaller streets, life went on. Through a sequence of images of street scenes and COVID-related signage, I discuss ethnographically the importance of the informal sector for providing the basic necessities of life in the city. This is especially true for the basic provision and sale of food. Images of street markets show the key roles of women to ensure these essential tasks were not disrupted during the pandemic. This informal sector work, like the role of women in society in particular, is rendered invisible, considered routine and habitual. The sudden disruption from COVID-19 brought into view daily patterns of life and work, and placed them temporarily in a new light.

\section{INDEX}

Keywords: COVID-19, visual ethnography, invisibility, informal sector, gender, Vietnam Mots-clés: COVID-19, ethnographie visuelle, invisibilité, secteur informel, genre, Vietnam

\section{AUTHOR}

\section{CHRISTOPHE ROBERT}

Christophe Robert, christo.robert@gmail.com, is a Lecturer at Loyola University Chicago, Vietnam Center, Ho Chi Minh City. He recently published:

- Robert C., 2014. Dead Zone: Pollution, Contamination, and the Neglected Dead in Post-War Saigon. In Finn Stepputat ed., Governing the Dead: Sovereignty and the Politics of Dead Bodies. Manchester University Press, 2014.

- Robert C., 2016. Review of It's a Living: Work and Life in Vietnam Today, by Gerard Sasges (NUS Press, 2013). Journal of Vietnamese Studies [Online], vol. 10, n 4, p. 127-131. DOI: https:// doi.org/10.1525/jvs.2015.10.4.127

- Robert C., 2019. In One's Breath, Nothing Stands Still. Journal of Vietnamese Studies [Online], vol. 14, n 2, p. 145-154. DOI: https://doi.org/10.1525/vs.2019.14.2.145 